\begin{tabular}{l}
\hline Jurnal Scripta Teologi dan Pelayanan Kontekstual \\
ISSN 2086-5368 (Print) \\
ISSN \\
Http://ejournal.stte.ac.id \\
Vol.2, No.2, pp. 113-130, 2017
\end{tabular}

\title{
Signifikansi Pendidikan Moral dan Spiritual Kristen Bagi Anak Remaja Usia 12-17
}

\begin{tabular}{l} 
ST \\
\hline INFO ARTIKEL \\
\hline Sejarah Artikel: \\
Diterima: 07 Okt 2017 \\
Direvisi : 15 Okt 2017 \\
Disetujui: 20 Okt 2017 \\
Dipublikasi: 28 Okt \\
2017
\end{tabular}

\section{Kata Kunci:}

keyword one, keyword two, keyword three.

Keywords:

keyword one, keyword two, keyword three.

Aris Elisa Tembay

STT Ebenhaezer Tanjung Enim, Aristembay@gmail.com

\section{ABSTRAK}

Proses perkembangan masa remaja dalam menemukan jati dirinya sangat bergantung pada beberapa unsur yakni orang tua, gereja, sekolah dan lingkungan sosial. Dalam hal ini orang tua secara khusus memegang peranan penting, dimana Allah sendiri yang telah memberi tanggung jawab kepada orang tua untuk mengasihi, melindungi, mendidik, dan mendisiplin anak-anak mereka. Orang tua merupakan faktor terpenting dalam pembentukan kepribadian anak remaja. Pendidikan spiritual kristen merupakan kebutuhan yang mendasar, yang harus diterapkan dalam kehidupan anak remaja. Pendidikan 'spiritual' bersifat kejiwaan (rohani, batin), yang juga dipahami sebagai spirit yakni sumber kekuatan, semangat hidup untuk bertumbuh, dan berkembang dalam semua bidang kehidupan di dunia ini, baik secara pribadi maupun bersama orang lain, yang kita peroleh di dalam perjumpaan dengan Allah, sesama dan diri sendiri. Pendidikan spiritual kristen anak remaja merupakan tugas utama orang tua, sebagaimana Allah sendiri menghendaki kedua orang tua membimbing anak mereka untuk mengenal dan takut akan Allah. Pendidikan spiritual kristen akan membantu anak remaja berpartisipasi dalam imannya, agar mereka menjadi orang Kristen yang dewasa. Kegiatan belajar biasanya sangat individual, dan memberi perhatian besar terhadap pengarahan rohani, membimbing individu memasuki bentuk kedewasaan yang lebih kompleks.

\footnotetext{
ABSTRACT

The process of development in adolescence in finding one's true identity is very dependent on several elements namely parents, church, school and social environment. In this case parents specifically play an important role, where God himself has given responsibility to parents to love, protect, educate, and discipline their children. Parents are the most important factor in shaping the personality of teenagers. Christian spiritual education is a basic need, which must be applied in the lives of teenagers. 'Spiritual' education is spiritual (spiritual, mental), which is also understood as spirit which is a source of strength, a spirit of life to grow, and develop in all areas of life in this world, both personally and with others, which we get in encounter with God, others and yourself. Christian spiritual education of teenagers is
} 
the main task of parents, as God himself wants both parents to guide their children to know and fear God. Christian spiritual education will help teenagers participate in their faith, so that they become mature Christians. Learning activities are usually very individual, and pay great attention to spiritual direction, guiding individuals into more complex forms of maturity.

\section{Pendahuluan}

Akhir-akhir ini kasus pelecehan seksual semakin meningkat, berbagai media informasi baik televisi, tabloid atau koran, dan juga dari layanan internet memuat dan menyuarakan fenomena yang terjadi pada saat ini. Hal ini sangatlah memprihatinkan dan merisaukan semua pihak.

Koordinator Komnas Perlindungan Anak Indonesia (KPAl), Arist Merdeka Sirait menjelaskan; "berdasarkan data KPAI 58\% kejahatan kekerasan pada anak merupakan kekerasan seksual yang diikuti dengan pembunuhan". Menyikapi grafik kekerasan yang terus meningkat, pemerintah Republik Indonesia menetapkan status darurat terhadap kekerasan seksual pada anak di negeri ini.

Lebih dari 3.000 pelanggaran yang dilakukan terhadap anak-anak dengan menggunakan teknologi dunia maya sejak tahun lalu, hal itu termasuk menghasut anak-anak untuk melakukan seks, dan 100 pemerkosa. Korban sebagian besar berusia 13 tahun. Ada sekitar 272 yang berusia di bawah 10 tahun, dan yang termuda bayi usia satu tahun. Angka-angka itu mengkonfirmasi bahwa dunia online memainkan peran penting dalam pelecehan seksual terhadap anak-anak di Inggris. Volume terbesar serangan seksual dan pemerkosaan anak melibatkan penggunaan internet. Anak-anak menghabiskan lebih banyak waktunya di depan internet, dan menggunakan media sosial. Internet Watch Foundation mengungkapkan; "jumlah halaman web yang terdeteksi mengandung gambar pelecehan seksual terhadap anak, dan ini diidentifikas imenurunkan lebih dari 68.000 situs yang berisi pelecehan seks pada anak."

Penulis mengamati berita kabar siang yang ditayangkan di chanel TV One, menjelaskan bahwa; "tahun 2012 s/d tahun 2014 tindak kekerasan dan pelecehan seksual terhadap anak sangat tinggi, dan tahun 2015 hingga saat ini (2016) dipaparkan ada 3.300 korban pelecehan seksual yang sudah terjadi, kasus kekerasan dan pelecehan seksual terhadap anak semakin buruk, dimana pelaku kekerasan dan pelecehan seksual tersebut banyak terdapat anak usia remaja."

Kasus pelecehan seksual kepada anak-anak di bawah umur telah menjadi fenomena yang terus berkembang. Menurut Dan B. Allender menjelaskan; "pelecehan seksual itu harus dimengerti secara benar, yakni kontak atau interak siapapun (psikologis, fisiologis) antara seorang anak dengan orang dewasa, yang memanfaatkan anak-anak untuk rangsangan seksual pelaku atau orang lain. Bagong Suyanto \& Sri Sanituti Hariadi (1992) menyatakan, bahwa: pelecehan seksual sesungguhnya adalah bentuk perlakuan yang tidak wajar kepada seseorang atau kelompok, akibatnya ada hubungan dominasi antara satu dengan yang lain.

Berikut ini penulis mencantumkan beberapa contoh kasus pelecehan seksual yang terjadi pada anak remaja:

Pertama, Hal yang serupa terjadi di Semarang, yang mengabarkan bahwa seorang gadis bernama Eiodia Elishabeth K. (Yoke) kelas 2 SMA, diperkosa oleh teman kakaknya. Kedua, Seorang siswi kelas 2 SMP berinisial "N" dilecehkan oleh seorang siswa laki-laki satu sekolahnya, "N" dilecehkan secara verbal/lewat kata-kata. Semenjak 
dilecehkan dengan kata-kata dan juga pernah dirabah membuat "N" trauma dan menjadi tertutup hingga saat ini.

Dengan melihat kasus-kasus pelecehan seksual yang terjadi pada anak remaja, hal ini merupakan masalah serius yang harus diperhatikan, dan menjadi fokus untuk ditangani sesegera mungkin. Masalah ini menjadi peringatan dan tanggung jawab bersama (orang tua, gereja dan sekolah) dalam mendidik dan mengarahkan anak-anak remaja. Mereka sangat membutuhkan perhatian khusus dalam perkembangan masa remajanya, terutama perhatian orang tua yang seharusnya memiliki waktu lebih banyak bersama-sama dengan anak remaja.

Minimnya pendidikan moral dan spiritual kristen akan sangat mempengaruhi perkembangan anak remaja dan memberi dampak yang sangat buruk, sehingga mengakibatkan remaja terjebak dalam masalah besar, dan dapat menghancurkan masa depannya sendiri. Remaja sangat mudah terpengaruh oleh perkembangan zaman, terlebih lagi dalam pergaulan mereka, dan hal ini tidaklah baik, karena Alkitab, dalam 1 Korintus 15: 33 dengan jelas dan tegas menyatakan bahwa: "Janganlah kamu sesat, pergaulan yang buruk merusak kebiasaan yang baik".

Anak remaja usia 12-17 tahun memerlukan perhatian penuh, dimana masa ini merupakan masa mereka memasuki dunia remaja. Anak remaja sedang mengalami masa transisi dimana seorang anak sangat bergantung penuh kepada orang dewasa, dalam hal ini orang dewasa bertanggungjawab penuh atas dirinya sendiri dan orang lain. Anak remaja harus mendapat pembinaan agar mengerti bahwa mereka adalah pribadi yang berharga. Seperti yang tertulis dalam Surat Paulus kepada Timotius:"beritakanlah dan ajarkanlah semuanya itu. Jangan seorangpun menganggap engkau rendah karena engkau muda. Jadilah teladan bagi orang-orang percaya dalam perkataanmu, dalam tingkah lakumu, dalam kasihmu, dalam kesetiaanmu dan dalam kesucianmu. Sementara itu, sampai aku datang bertekunlah dalam membaca kitabkitab Suci dalam membangun dan dalam mengajar.

Banyak varian yang menjadi faktor terjadinya kasus kekerasan dan pelecehan seksual salah satunya adalah kerentanan dalam keluarga, dimana tidak adanya kehadiran secara psikologis, dan kehilangan identitas. Dengan memberikan pendidikan moral dan spiritualkristenakan membentuk kepribadian dan menolong remaja tersebut dalam mencari identitas/jati dirinya sebagai remaja kristen yang baik.

\section{Metode Penelitian}

Penelitian ini adalah penelitian kualitatif deskriptif yakni penelitian yang menggambarkan atau melukiskan objek peneliti-an berdasarkan fakta-fakta yang tampak atau sebagaimana adanya. Nawawi dan Martini (1996:73).

Teknik pengumpulan data dalam penelitian ini dilakukan dengan pengamatan atau partisipasi langsung dan penelaahan dokumen.

\section{Hasil Dan Pembahasan}

Proses perkembangan masa remaja dalam menemukan jati dirinya sangat bergantung pada beberapa unsur yakni orang tua, gereja, sekolah dan lingkungan sosial. Dalam hal ini orang tua secara khusus memegang peranan penting, dimana Allah sendiri yang telah memberi tanggung jawab kepada orang tua untuk mengasihi, melindungi, mendidik, dan mendisiplin anak-anak mereka. Orang tua merupakan faktor terpenting dalam pembentukan kepribadian anak remaja. Berdasarkan hasil 
penelitian yang telah dilakukan, penulis menemukan bahwa anak remaja usia 12-17 tahun yang sedang dalam proses akil balik atau pencarian jati diri rentan sekali terhadap pelecehan seksual, penulis menemukan problematika yang banyak terjadi dilihat dari segi perkembangan seksual anak remaja usia 12-17 tahun, tidak adanya bimbingan dari orang tua, dan tekanan dari teman sebayanya.

\section{a. Problematika Anak Remaja Usia 12-17 Tahun}

\section{Kurangnya perhatian dan kasih sayang dari orang tua}

Anak remaja dalam perkembangannya mengalami banyak perubahan. Mereka sangat membutuhkan perhatian, kasih sayang dan bimbingan, dalam arti orang tua harus melakukan peranannya dengan menunjukkan perhatian dan kasih sayang kepada anak remajanya. BS. Sidjabat dalam bukunya: "Membesarkan Anak Dengan Kreatif" mengatakan bahwa:

Orang tualah yang bertanggung jawab dalam pertumbuhan iman dan karakter yang baik pada anak remaja. Orang tua dituntut berperan lebih efektif mendampingi anak remajanya dalam menjalani proses perubahan hidup anak remajanya, dengan memperlakukan mereka sebagai sahabat, sehingga kesadaran diri anak remaja sebagai pribadi yang berharga dan bertanggung jawab dapat berkembang lebih mudah.

Namun yang terjadi justru sebaliknya, banyak orang tua yang tidak melakukan peranannya dengan baik, sehingga anak remaja banyak yang melakukan ketidaktaatan hanya untuk mendapatkan perhatian dan kasih sayang. Pernyataan tersebut juga diungkapkan oleh Ibu SWB yang menjelaskan bahwa:

Anak remaja yang kurang kasih sayang dan perhatian dari orang tua cenderung mengalami pemberontakan, dimana kondisi mereka secara emosi yang labil, membuat tindakan mereka tanpa batasan, banyak anak remaja yang tidak mendapat pengenalan secara pribadi terhadap keselamatan di dalam Yesus Kristus, dan kurangnya kasih sayang membuat mereka berusaha mencari perhatian dan kasih sayang lewat orang lain, dan juga lewat media sosial yang memiliki berbagai macam layanan, tanpa memikirkan konsekunsi dari tindakan mereka yang dapat mengakibatkan mereka dalam masalah, dan tidak sedikit anak remaja yang telah menjadi korban pelecehan seksual sehingga mereka kehilangan masa depan.

Penjelasan yang diungkapkan oleh ibu SWB juga sama halnya dengan apa yang dikemukakan oleh ibu yang berinisial Ln, dalam penjelasannya menerangkan bahwa: Kurangnya perhatian dan kasih sayang terhadap anak remaja mengakibatkan anak remaja bisa bertindak diluar dugaan orang tua, mereka mencari kebahagiaan di luar, lewat teman, pacar, dan juga tidak sedikit yang terhipnotis oleh media sosial, lewat media sosial banyak yang membuat mereka terhibur dan lewat permainan games, video porno, dan juga seks lewat wabcam.

\section{Perkembangan seksual anak remaja}

Pertumbuhan yang wajar pada setiap anak adalah mempunyai identitas seksual yang pasti, yaitu masing-masing menyepakati identitasnya. Kesepakatan atau penerimaan diri itu berarti bahwa mereka dapat mengucap syukur kepada Allah bahwa mereka dilahirkan seperti apa adanya, yaitu laki-laki sebagai laki-laki dan perempuan sebagai perempuan. Tanpa penerimaan identitas seksual, seorang anak remaja akan 
merasa rendah diri dan sengsara dalam menjalani pergaulan dengan anak-anak remaja lainnya. Masa perkembangan seksual anak remaja memuncak, begitu cepat pada usia 12 tahun dan selambat-lambatnya pada usia 19 tahun bagi anak remaja pria, dan antara usia 10 sampai 17 tahun bagi anak remaja putri. Di antara segala masalah yang harus dihadapi oleh setiap anak remaja, bahaya seksuallah yang mencolok pada masa kini.

Banyak masalah seksual timbul sebagai akibat pendidikan yang tidak semestinya terjadi pada masa anak remaja. Ibu IS salah seorang dari orang tua anak remaja mengatakan pendapatnya, bahwa:

Orang tua yang tidak berpusat kepada Kristus, tidaklah harmonis, dan keluarga yang tidak memiliki pola didik yang baik terhadap anak remaja akan memberi dampak yang sangat buruk terhadap perkembangan anak remaja. Anak remaja bertumbuh menjadi pribadi yang tertutup, memberontak, dan tidak mau dikontrol dalam hal apapun. Anak remaja akan mencari sesuatu yang dianggapnya dapat membuatnya nyaman, dan cenderung kepada hal-hal yang negatif, yang dapat merusak masa depan anak remaja, antara lain pergaulan bebas, menggunakan narkoba, penyalahgunaan tehknologi hingga candu. Kehidupan anak remaja yang seperti ini akan menjebak dirinya sendiri dalam seks bebas. Tanpa disadari merusak masa depannya sendiri dan juga orang lain.

Pernyataan ibu IS tersebut menjelaskan bahwa situasi ataupun keadaan yang terjadi di kalangan anak remaja saat ini merupakan hal yang sangat buruk dalam perkembangan anak remaja. Hal tersebut juga diungkapkan oleh ibu $W$ yang mengatakan bahwa:

Orang tua yang tidak memberikan pendidikan dan pendampingan khusus terhadap anak remaja akan membentuk anak remaja menjadi tertutup terlebih dalam perkembangan seksual mereka, mereka cari tahu sendiri, baik itu lewat orang lain ataupun dari media sosial, akibatnya mereka banyak yang salah mengerti, bahkan kemungkinan besar anak remaja menjadi korban ataupun pelaku dari penyimpangan seksual.

Tidak adanya pendidikan bagi anak remaja akan membentuk anak remaja tersebut menjadi pribadi yang tertutup demikian yang diungkapkan oleh ibu W. Hal inipun diperjelas dengan pernyataan yang diungkapkan oleh ibu FA, bahwa:

Tidak adanya pengetahuan seks yang benar akan membuat anak remaja menjadi pribadi yang tertutup, tidak menghargai seks, dan bahkan anak remaja tersebut melakukan dosa seksual. Anak remaja tidak dapat menguasai diri, dengan rasa ingin tahu yang tinggi, dan gejolak seksual yang sedang memuncak membuat mereka melakukan penyimpangan seksual, anak remaja menjadi korban ataupun pelaku dari dosa seksual.

\section{Tekanan dari teman sebaya.}

Generasi muda zaman sekarang menghadapi berbagai tekanan yang unik. Mereka mengalami informasi yang serba cepat dan bertubi-tubi dari media yang biasanya membawa nilai yang tidak etis bagi iman dan kepercayaan Kristen. Perlu diperhatikan bahwa anak-anak remaja sekarang ini dibesarkan dalam masyarakat bukan Kristen yang keras dan kacau. Anak remaja dalam perkembanganya benci akan kritikan. Disiplin, kritikan, dan nasihat dianggap sebagai penguasaan atas mereka dan mereka tidak mau dikuasai. Pada usia ini, nampak kesetiaan dan keterikatan lebih dialihkan kepada teman yang sebaya, baik lawan jenis maupun sesama jenis. 
Perubahan dalam hal berpakaian, cara berbicara, minat pada musik, kegiatan-kegiatan yang menggairahkan dan tingkah lakunyapun berhubungan dengan kelompok sebayanya.

Pada tahun 1977 Gebhard dengan jelas memperlihatkan apabila tiba pada masalah seks, maka yang pertama, ibulah [orang tua] yang mempunyai pengaruh yang menentukan, dengan kelas-kelas pendidikan seks dan bahan pendidikan seks jatuh pada nomor dua, dan yang nomor tiga adalah media masa. Apabila keterangan seks datangnya dari teman-teman sebayanya, maka kemungkinan besar mereka sudah terlibat dalam masalah hubungan seks, dan menurut Zelnik dan Kanter, ada kaitannya juga dengan kegiatan seks yang pernah dilakukannya sebelumnya. Tekanan dari teman sebaya menjadi sangat kuat jika hal itu mengarah kepada melakukan seks. Banyak anak remaja yang terpaksa, hingga akhirnya menikmati pergaulan seks akibat dari tekanan teman sebaya. Hal tersebut juga diperjelas dengan pernyataan oleh seorang remaja putri berinisial El, yang mengatakan bahwa:

Pelecehan sering terjadi dikalangan anak sekolah diakibatkan oleh tekanan dari teman sebaya dan hal tersebut terus berkembang hingga saat ini, baik itu secara verbal yaitu melecehkan secara fisik: merabah/menyentuh bagian tubuh yang sensitif/area terlarang; dan secara non verbal: pembicaraan "seksuality", melecehkan lewat perkataan yang sering disebut dengan "catthing calls".

Pernyataan EL menyiratkan bahwa pergaulan sangat mempengaruhi tingkah laku orang, terutama anak remaja yang masih sangat mudah untuk dipengaruhi. Orang tua dari anak remaja yang berusia 14 tahun berinisial Ln berpendapat bahwa pengaruh tekanan teman dan perkembangan tehknologi yang tak terkontrol membuat mereka mengalami kemerosotan moral dan spiritual mereka. Hal tersebut juga dibenarkan oleh Ibu HRS yang dalam pandangannya mengatakan bahwa:

Banyak anak remaja yang membuat orang tuanya cemas, karena sudah banyak anak remaja yang kehilangan kesempatan dan masa depan, dikarenakan pengaruh pergaulan dan tidak adanya perhatian yang aktif dari orang tua, dan dapat dikatakan bahwa anak remaja sebagai generasi muda tengah berada diambang kehancuran, dan tidak memiliki masa depan.

Dari berbagai pengamatan dan penjelasan yang telah diuraikan di atas, menerangkan bahwa orang tua yang tidak aktif dalam pernananya, pengaruh iptek, dan juga tekanan dari teman sebayanya, membuat anak remaja rentan sekali terhadap penyimpangan-penyimpangan, terlebih terhadap pengaruh pelecehan seksual yang menjadi fenomenal di kalangan anak remaja, dan ini merupakan hal yang penting untuk diperhatikan dan harus segera dicegah agar tidak mempengaruhi dan merusak masa depan anak remaja Kristen sebagai generasi muda.

\section{b. Faktor Penyebab Problematika Anak Remaja Usia 12-17 Tahun \\ 1. Etiket dan pergaulan}

Etiket adalah aturan sopan santun dan tata cara pergaulan yang baik antara sesama manusia. Etiket juga dapat diartikan sebagai rambu-rambu yang membantu mengetahui apa yang harus dilakukan dan yang tidak boleh dilakukan dalam situasi tertentu.

Terkaitan hubungan dengan sesama manusia maka komunikasi dan sosialisasi sangat memerlukan etika. Etika tersebut mengenai cara berpacaran yang benar, aturan 
sopan santun yang umum, sampai cara bergaul yang baik dalam situasi yang spesifik. Etika remaja juga meliputi komunikasi dengan orang lain, cara bersikap di depan umum, dan juga cara berbusana yang pantas untuk setiap kesempatan. Cara berpakaian, model rambut, dan dandanannya, serta cara makan dan minum itu menunjukkan tabiat baik atau buruknya seseorang. Sebagai kaum remaja pergaulan merupakan bagian penting yang tidak terpisahkan dalam perkembangannya. Terutama untuk menambah waawasan dan pengetahuan. Dalam hal ini sangatlah penting peranan orang tua untuk mengawasi tingkah laku anak remajanya agar tidak terjerumus dalam pergaulan bebas.

Dewasa ini, mulai dari tata krama terhadap orang dewasa, kelakukan ugal-ugalan di jalan raya, hingga perilaku yang menyimpang, seperti narkoba dan seks bebas terjadi dikalangan anak remaja. Bentrok dengan orang tuapun kerap terjadi lantaran anak remaja kurang memahami etiket bersopan santun. Dalam proses pencarian jati diri para remaja banyak terjebak dalam pergaulan bebas, dan telah mencapai titik kekhawatiran yang cukup parah, terutama seks bebas yang melanda kalangan anak SLTA, juga merambat di kalangan anak SLTP. Hal inipun dikemukakan oleh ibu W dalam pendapatnya menyatakan bahwa:

Anak remaja saat ini tidak terkontrol, akibat kurangnya perhatian orang tua, baik dari segi pergaulan, penggunaan gadged, bahkan anak remaja juga banyak yang tidak memiliki etika dalam berpakaian, hal ini menimbulkan penyimpanganpenyimpangan, seperti halnya pelecehan seksual yang terjadi pada anak remaja saat ini, dan telah banyak memakan korban.

Dari uraian tersebut di atas menjelaskan bahwa etiket dan pergaulan anak sudah tidak wajar, dan menunjukkan kemerosotan moral dalam kehidupan anak remaja. Hal ini mengakibatkan rusaknya generasi muda.

\section{Kelalaian orang tua}

Orang tua merupakan oknum penting dalam keluarga, dimana orang tua memiliki peranan dalam menciptakan kesejahteraan umum melalui bimbingan dan pendidikan anaknya secara bertanggung jawab. Tanggung jawab utama dalam pembinaan anak harus diterima oleh orang tua, terutama ayah.

Namun ada banyak orang tua tidak menyadari kelalaian dan kekurangan mereka, betapa pentingnya peranan orang tua dalam pembentukan pribadi anak. Kesalahan terbesar orang tua adalah banyaknya waktu yang tersita untuk mengejar uang sekalipun uang itu demi pendidikan anaknya. Semestinya waktu yang dipakainya itu disediakan bagi anaknya karena pendidikan di rumah lebih penting daripada pendidikan formal. Pernyataan ibu IS terkait dengan perkembangan anak remaja saat ini, menjelaskan bahwa:

Dalam perkembangan anak remaja saat ini ditemukan banyak orang tua yang tidak melakukan pernananya dengan baik (ayah ataupun ibu), sehingga orang tua kurang memahami perkembangan anak, kurang memberikan pendidikan moral dan spiritual, dan bahkan jarang sekali memberikan perhatian dan kasih sayang.

Pernyataan tersebut di atas, dapat dipahami bahwa peranan orang tua dalam mendidik anak adalah hal yang sangat penting untuk dilakukan. Beverly La Haye dalam bukunya yang berjudul: "Memahami Temperamen Anak Anda", menjelaskan bahwa: 
Apa bila orang tua mengerti kecenderungan yang wajar dalam perkembangan anak remajanya, maka akan lebih bersungguh-sungguh membimbing anaknya untuk mengenal Kristus dan mengajarinya untuk menjauhi yang jahat dan melakukan apa yang yang baik dalam kehidupannya.

Dalam hal ini banyak orang tua yang perlu menyadari betapa besar dampak dari kelalaian mereka untuk mengajar, orang tua harus bersungguh-sungguh dalam memperhatikan perkembangan anak remaja, agar anak remaja yang rentan sekali terpengaruh terhadap perkembangan zaman (pelecehan seksual) dapat dicegah.

\section{Pengaruh lingkungan sosial}

Tidak hanya iptek yang memberi pengaruh kuat terhadap perkembangan anak remaja. Selain pengaruh keluarga/orang tua, lingkungan sosial juga memiliki pengaruh yang cukup kuat dalam perkembangan anak remaja. Dalam hal ini lingkungan sosial dapat memberikan pengajaran-pengajaran yang positif apabila remaja dapat memilih dengan baik dalam berteman atau bergabung dalam kelompok yang tepat dalam pergaulannya.

\section{c. Dampak Problematika Anak Remaja Usia 12-17 Tahun \\ 1. Anak remaja}

Dampak yang terjadi akibat dari masalah-masalah yang dialami oleh anak remaja terhadap pelecehan seksual mengakibatkan anak remaja menjadi minder, tertutup, suka menyendiri, dan bahkan mengalami trauma terhadap lawan jenis, dan bahkan mereka kehilangan masa depannya, dan tidak jarang mereka bunuh diri.

Hal serupa juga diungkapkan oleh seorang ibu yang berinisial vs bahwa pelecehan seksual yang terjadi terhadap anak remaja tersebut, akan mengalami depresi atau trauma yang mendalam dan akan sulit untuk bangkit kembali, dari segi kesehatan dapat terkontaminasi penyakit, anak remaja tersebut tertekan hingga ia depresi, dan tidak sedikit yang mencoba bunuh diri.

Jadi dapat dipahami bahwa pribadi anak remaja yang mengalami masalah, ataupun korban bahkan pelaku dari pelecehan seksual, berdampak hebat pada dirinya sendiri.

\section{Keluarga (Orang Tua)}

Problematika ataupun masalah yang terjadi terhadap anak remaja juga berdampak dalam keluarga. Keluarga yang merupakan bagian penting dari anak remaja. Anak yang tumbuh tanpa mendapatkan didikan atau disiplin sama sekali dari orang tua, akan memperoleh bahaya di masa depannya, dan kelak orang tua anak itu pun akan mengalami banyak kesedihan dan sakit hati.

Seperti yang telah penulis uraikan pada bagian sebelumnya telah banyak anak remaja yang menjadi korban pelecehan seksual akibat dari kurangnya bimbingan dan kasih sayang dari orang tua, ibu VS juga mempertegas, bahwa:

Masalah yang timbul tidak dapat terelakkan lagi, keluarga juga mengalami goncangan jiwa, shok/terkejut, kecewa, tertekan, dan malu terhadap orang lain [tetangga, rekan kerja, dan dalam persekutuan]. 
Kalau orang tua tidak menyediakan waktu bagi anak-anaknya, masa tuanya akan penuh dengan kedukaan. Meskipun duduk di rumah mewah, mereka akan merasa sengsara jika merenungkan nasib anak-anaknya yang bermoral rusak. Mungkin mereka akan kesepian karena anak-anak tidak menghiraukannya lagi. Sengsara semacam ini tidak dapat diobati dengan uang. Dalam hal itu lebih baik hidup miskin daripada merusak hubungan keluarga [orang tua dan anak remaja].

\section{Lingkungan sosial}

Masalah-masalah yang terjadi dalam diri seseorang tidak hanya berdampak pada dirinya sendiri maupun bagi keluarganya, tetapi juga memberi dampak dalam lingkungan sosialnya. Demikian juga yang dialami oleh seorang anak remaja ketika ia sedang berhadapan dengan masalah pelecehan seksual, maka hal ini juga akan mempengaruhi kehidupan sosial anak remaja tersebut. Pengaruh lingkungan yang tidak didasarkan Firman Allah juga mempengaruhi kepribadian dan perilaku seseorang.

Melihat problematika yang telah dipaparkan di atas, maka dapat disimpulkan bahwa dampak yang terjadi pada diri anak remaja dalam lingkungan sosialnya yakni antara lain: anak remaja tersebut akan dibenci, dihina dan dicap sebagai trouble maker/pembuat masalah. Selain itu anak remaja tersebut akan dijauhi oleh orang, tidak dianggap, bahkan tidak difungsikan dalam kegiatan-kegiatan sosial yang ada.

Berdasarkan problematika yang telah penulis paparkan di atas, maka dapat disimpulkan bahwa perkembangan anak remaja usia 12-17 tahun saat ini sangat tidak baik, dalam arti masalah yang terjadi terhadap anak remaja adalah hal yang sangat serius, dimana banyak anak remaja yang hancur hidupnya karena kehilangan masa depan akibat kurangnya dan bahkan tidak adanya pendidikan moral dan spiritual dalam keluarga, orang tua yang tidak aktif dalam mendidik dan memperhatikan perkembangan anak remajanya menentukan masa depan.

Semua problematika yang terjadi dikalangan anak remaja harus segera ditangani, dengan melakukan upaya yang dapat mencegah penyimpangan atapun pelecehan seksual yang terjadi terhadap anak remaja, jika upaya pencegahan tidak segera dilakukan maka, kemungkinan besar akan korban pelecehan seksual akan terus bertambah dan juga pelaku pelecehan seksual semakin merajalela dan semakin meningkatnya kriminalitas di kalangan anak remaja.

Dalam hal ini peran orang tua (ayah ataupun ibu) merupakan ujung tombak pencegahan, dengan menerapkan pentingnya pendidikan moral dan spiritual bagi anak remaja usia 12-17 tahun, harus aktif dan dengan perhatian ekstra. Sebagaimana Tuhan sendiri telah mengutus orang tua menjadi agen pendidikan untuk membimbing anakanaknya untuk hidup takut akan Tuhan, terlebih lagi dalam menyikapi realita kehidupan anak remaja terhadap kasus pelecehan seksual yang menjadi fenomenal di masa ini. Kehidupan anak remaja sebagai generasi muda dalam perkembangannya akan lebih muda, proses akil balik atau pencarian jati diri anak remaja tersebut akan tertolong dan membuat anak remaja tersebut dapat berkembang dengan baik, sehingga menjadi pribadi yang diharapkan dan dapat diandalkan sebagai generasi muda yang takut akan Tuhan. 


\section{d. Penerapan Pendidikan Moral Dan Spiritual Kristen Sebagai Upaya Pencegahan Kasus Pelecehan Seksual}

Berdasarkan problematika yang terjadi di tengah-tengah anak remaja usia 12-17 tahun saat ini, maka penting sekali untuk diperhatikan dan ditangani sesegera mungkin, oleh karena itu dalam bagian ini penulis akan menguraikan penerapan pendidikan moral dan spiritual bagi anak remaja usia 12-17 tahun sebagai upaya pencegahan kasus pelecehan seksual yaitu:

\section{Pendidikan Moral Dan Spiritual Kristen Bagi Anak Remaja Usia 12-17 Tahun 1. Pendidikan moral}

Pendidikan moral merupakan sesuatu kebutuhan atau suatu ajaran yang harus ditekankan dalam perkembangan anak-anak remaja. Dalam kamus psikologi, moral dijelaskan sebagai istilah yang diterapkan pada individu atau kelompok yang berhubungan dengan keadaan pengontrolan diri, keyakinan diri dan kedisiplinan tindakan. Melihat kebutuhan anak remaja saat ini, penting sekali ditekankan pendidikan moral agar anak remaja tidak mudah terpengaruh akan hal-hal yang negatif, seperti penyimpangan-penyimpangan moral yang terjadi dalam kehidupan anak remaja, di zaman ini sudah banyak anak remaja yang menjadi korban kasus pelecehan seksual dan ironisnya lagi para pelaku pelecehan seksual tersebut adalah anak remaja, dan tidak sedikit kasus kekerasan tersebut berujung pada kematian, contoh: kasus Yuyun seorang siswi Sekolah Menengah Pertama yang diperkosa oleh 14 orang, 7 diantaranya masih anak remaja, perbuatan keji mereka telah membunuh Yuyun.

Problematika anak remaja terkait dengan pendidikan moral menunjukkan bahwa pendidikan moral merupakan kebutuhan yang mendasar dan mendesak dalam perkembangan anak remaja. Untuk itu pendidikan moral sangat penting diterapkan dalam keluarga kepada anak remajanya agar mereka dapat memiliki moral yang baik. Pendidikan moral dapat diterapkan dengan menunjukkan teladan. "Jadikanlah dirimu sendiri suatu teladan dalam berbuat baik. Hendaklah engkau jujur dan bersungguhsungguh dalam pengajaranmu, sehat dan tidak bercela (Tit. 2: 7)." Ibu W juga mengatakan dengan melakukan hal-hal yang benar dan konsisten akan mengajarkan kepada anak apa yang pantas dilakukan, dan apa yang tidak pantas dilakukan. Terlebih melalui pengajaran Firman Tuhan yang menegaskan untuk hidup takut akan Tuhan (Ams. 1: 7a). Takut akan Tuhan adalah didikan yang mendatangkan hikmat, dan kerendahan hati melalui kehormatan, dan mendorong orang untuk hidup kudus, dan memelihara kesucian, dan juga bekerja dengan motivasi yang benar.

Jadi dengan kesadaran akan pentingnya pendidikan moral terhadap anak remaja, akan menolong mereka menjadi pribadi yang bermoral.

\section{Pendidikan spiritual kristen}

Pendidikan spiritual kristen merupakan kebutuhan yang mendasar, yang harus diterapkan dalam kehidupan anak remaja. Pendidikan 'spiritual' bersifat kejiwaan (rohani, batin), yang juga dipahami sebagai spirit yakni sumber kekuatan, semangat hidup untuk bertumbuh, dan berkembang dalam semua bidang kehidupan di dunia ini, baik secara pribadi maupun bersama orang lain, yang kita peroleh di dalam perjumpaan dengan Allah, sesama dan diri sendiri. 
Pendidikan spiritual kristen anak remaja merupakan tugas utama orang tua, sebagaimana Allah sendiri menghendaki kedua orang tua membimbing anak mereka untuk mengenal dan takut akan Allah. Pendidikan spiritual kristen akan membantu anak remaja berpartisipasi dalam imannya, agar mereka menjadi orang Kristen yang dewasa. Kegiatan belajar biasanya sangat individual, dan memberi perhatian besar terhadap pengarahan rohani, membimbing individu memasuki bentuk kedewasaan yang lebih kompleks. Melihat problematika spiritual kristen anak remaja yang semakin berkembang sesuai umurnya, maka pendidikan spiritual sangat penting untuk diterapkan, yakni dengan upaya mengajak anak mengenal Allah, dan ini harus pula menjadi gaya hidup dari orang tua baik di rumah maupun di luar rumah ketika bersama dengan anaknya. Orang tua harus menggunakan, bahkan merebut kesempatan untuk mendemonstrasikan sikap dan perbuatan yang memuliakan Tuhan.

Perkembangan spiritual kristen anak remaja harus diperhatikan dan diterapkan sejak dini dalam keluarga. Sebagai orang tua yang sudah mengaku iman percaya kepada Tuhan di dalam Yesus Kristus, harus membaptiskan anak mereka, sesuai dengan perintah Yesus sendiri (Mat. 28: 19-20), yang menandakan bahwa anak telah menjadi milik Allah. Seiring pengenalan anak akan Allah dalam keluarga, orang tua juga harus membawa anaknya ke sekolah minggu, tempat dimana anak juga menerima pengajaran dan pengenalan akan Allah. Namun orang tua tidak dapat sepenuhnya menyerahkan pertumbuhan iman anak melalui sekolah minggu, karena adanya keterbatasan, baik itu dari segi waktu ataupun pembina sekolah minggu yang tidak dapat menjangkau semua anak sekolah minggu. Baptisan ataupun persekutuan yang diikuti tidaklah menyelamatkan selama anak belum menerima ataupun mengalami perjumpaan dengan Yesus Kristus sang juru selamat secara pribadi. Baptisan usia anak dilanjutkan dengan sidi, maka dalam hal ini anak remaja usia dari usia 15-17 tahun dapat mengikuti kegiatan Katekisasi agar dapat disidi. Melalui katekisasi anak remaja akan belajar, dan dapat mengetahui siapa Allah yang mereka imani, dan mereka dapat meyakini lebih lagi bahwa Yesus Kristuslah satu-satunya juru selamat yang dapat menebus mereka dari maut akibat dosa. Peneguhan sidi adalah kesempatan untuk mengakui iman di hadapan jemaat sebagai pernyataan, bahwa janji orang tua telah ditepati dan sang anak percaya kepada Yesus Kristus. Melalui peneguhan sidi, seseorang diterima sebagai anggota jemaat yang bertanggung jawab mengambil bagian dalam pelayanan jemaat, dan diizinkan ikut dalam Perjamuan Kudus.

Melalui uraian penerapan pendidikan moral dan spiritual bagi anak remaja usia 1217 tahun, akan membawa mereka ke arah yang baik dan benar di hadapan Tuhan dan sesama, terlebih lagi dalam menyikapi problematika anak remaja saat ini.

\section{e. Upaya Pencegahan Kasus Pelecehan Seksual Terhadap Anak Remaja Usia 12-17 Tahun \\ 1. Peranan keluarga}

Dalam kehidupan keluarga kristen pendidikan moral dan spiritual merupakan kebutuhan dasar yang harus ditanamkan pada diri anak, agar anak remaja dapat berkembang lebih mudah. Orang tua tidak mungkin dapat membawa anak mereka untuk percaya kepada Yesus Kristus sebagai Tuhan dan juruselamat, kalau orang tua sendiri belum mengenal Dia. Janji-janji Tuhan hanya diberikan kepada orang yang takut akan Dia dan melakukan titah-Nya (Maz. 103: 17-18). Untuk itu keluarga kristen harus hidup takut akan Tuhan, sebagaimana dalam takut akan Tuhan ada ketentraman besar, 
bahkan ada perlindungan bagi anak-anak-Nya, dan takut akan Tuhan adalah sumber kehidupan sehingga orang terhindar dari jerat maut. Dalam Perjanjian Baru dijelaskan bahwa dengan takut akan Tuhan akan mendorong orang untuk hidup kudus dan memelihara kesucian (2 Kor. 7: 1).

Dalam hal ini sebagai keluarga kristen harus melakukan upaya untuk mencegah terjadinya pelecehan seksual terhadap anak remaja, yakni mendidik anak remaja secara moral dan spiritual, memberikan perhatian dan kasih sayang, serta memberikan pemahaman yang benar tentang seks, mengadakan kebaktian keluarga dan saat teduh.

\section{Mengajarkan etiket pergaulan kepada anak remaja}

Etiket merupakan bagian penting dalam diri setiap orang, begitu juga dengan remaja. Dalam berkomunikasi dengan sesama manusia diperlukan tata krama, baik dari etiket berkomunikasi, etiket di rumah, si sekolah, di tempat umum, di perjalanan, etiket dalam berbusana, serta dalam pergaulan. Etiket adalah aturan sopan santun dan tata cara pergaulan yang baik antara sesama manusia. Etiket juga dapat diartikan sebagai rambu-rambu yang membantu mengetahui apa yang harus dilakukan dan yang tidak boleh dilakukan dalam situasi tertentu.

Etiket pergaulan harus diajarkan oleh orang tua kepada anak remajanya. Sebagaimana yang sudah diuraikan dalam bab III, etiket merupakan bagian penting yang tidak terpisahkan dalam perkembangan anak remaja. Terutama untuk menambah waawasan dan pengetahuan. Dalam hal ini sangatlah penting peranan orang tua untuk mengawasi tingkah laku anak remajanya agar tidak terjerumus dalam pergaulan bebas. Jadi etiket pergaulan sangat penting bagi anak remaja. Dengan memahami etiket pergaulan, anak remaja akan lebih berhasil dalam pergaulannya. Dengan bekal etiket yang baik akan membuat anak remaja mudah dalam menyesuaikan diri dan diterima oleh siapa pun dan dalam situasi apa pun. Anak remaja merasa aman meski di lingkungan baru sekalipun.

\section{Mendidik secara moral dan spiritual kristen.}

Sebagai anak remaja kristen pendidikan moral dan spiritual merupakan hal yang esensial. Dalam hal ini dituntut peran aktif orang tua dalam mendidik anak remajanya, dan harus mengajarkan apa yang sudah Tuhan perintahkan. Orang tua harus memperhatikan, dan mengajarkan secara berulang-ulang kepada anak-anaknya dan membicarakannya baik dalam posisi duduk, sedang berjalan, apabila sedang berbaring ataupun sedang bangun, agar anak remaja hidup takut akan Tuhan, mengasihi Tuhan dengan segenap hati, dan segenap jiwa dan dengan segenap kekuatannya. Dengan mengarahkan anak hidup takut akan Tuhan, maka secara moral dan spiritual anak remaja akan mudah diarahkan dan terhidar dari penyimpangan-penyimpangan, salah satunya pelecehan seksual terhadap anak remaja.

\section{Memberikan perhatian dan kasih sayang}

Kasih sayang dan perhatian orang tua tidak tergantikan oleh materi atau apapun. Oleh sebab itu orang tua harus selalu memperhatikan kebutuhan dasar anak remajanya yaitu kebutuhan kasih sayang dan perhatian orang tua, sehingga anak remajapun akan belajar mengasihi orang lain. Adalah hal yang penting bagi anak remaja menemukan kasih, sukacita, perhatian dan kesediaan untuk didengarkan dalam rumah, untuk itu 
jadilah teman bagi anak-anak remaja, karena itu merupakan hal terpenting bagi anak remeja dalam masanya, jangan sampai anak remaja tidak mendapat perhatian dan kasih sayang orang tua, karena mereka akan melakukan apa saja untuk mendapatkan kasih sayang dan perhatian bahkan dengan bersetubuh sekalipun, anak remaja akan melakukannya.

Dengan kasih sayang dan perhatian dari orang tua kepada anak remaja, menjadikan mereka pribadi yang utuh, dalam arti mereka tidak akan mencari kasih sayang diluar keluarga (orang tua).

\section{Memberikan pemahaman yang benar tentang seks}

Dorongan seksual yang kuat muncul dalam perkembangan anak remaja, dan pada usia ini selalu ada rasa ingin tahu. Dalam hal ini banyak yang menganggap penyelewengan seks sebagai masalah sepele, bahwa pengalaman seksual itu sesuai kodrat, dan tidak mungkin tuntutan kodrat dapat disebut dosa. Kenyataan ini harus menyadarkan orang tua untuk tidak lalai akan tugas tanggung jawabnya untuk mengajarkan seksualitas yang benar sebagai tugas yang diamanatkan Allah.

Dalam hal ini orang tua harus menerangkan secara terbuka, dimana seks itu penting, baik, kudus dan patut dihormati karena Alkitab yang mengatakaNya demikian. Seks adalah kudus dalam pernikahan, akan menjadi tidak kudus kalau dilakukan di luar pernikahan, bahkan Firman Tuhan menyebutnya sebagai perzinahan. Seks kudus sesuai ciptaan Allah adalah menggunakan organ-organ seks sesuai rancangan dan peruntukkannya. Sikap takut akan Tuhan harus ditanamkan dalam diri anak remaja menjadikan mereka bertanggung jawab atas sikap dan tingkah lakunya. Dan anak remaja dapat dicegah pelecehan seksual.

\section{Mengadakan kebaktian keluarga dan saat teduh}

Dalam kehidupan keluarga ada dua hal penting yang harus dilakukan agar keluarga tersebut dapat tumbuh secara rohani menuju kepada kedewasaan penuh, yakni dengan mengadakan kebaktian keluarga dan saat teduh. Kebaktian keluarga adalah ibadah yang dilakukan secara bersama, oleh seluruh anggota keluarga dan seisi rumah. Dalam kebaktian keluarga semua anggota keluarga terlibat, misalnya ayah menyampaikan Firman Tuhan, ibu memimpin pokok doa, anak mimpin pujian. Kemudian, dilakukan secara bergantian. Kebaktian keluarga dapat diadakan pada malam hari sehingga semua anggota keluarga dapat mengikutinya. Bila memungkinkan kebaktian keluarga dapat dilakukan setiap hari atau dua hari satu kali dengan waktu 30 sampai 60 menit.

\section{Saat Teduh}

Saat teduh merupakan waktu yang disisihkan setiap hari oleh setiap pribadi, biasanya pagi hari, untuk bersekutu dengan Allah, melalui doa, pujian, dan membaca firman Allah. Saat teduh sangat penting sebagai sarana pertumbuhan rohani. Saat teduh ini harus dilaksanakan setiap hari, karna mendisiplin diri dengan mengadakan saat teduh akan membawa pertumbuhan rohani dan perilaku yang semakin diperbaharui. 


\section{Gereja membimbing keluarga kristen}

Gereja memiliki tugas untuk memberikan pengajaran bagi keluarga kristen dan mendukung keluarga kristen dalam menunaikan tugas pendidikan dan pengajaran. Gereja harus terus menyatakan andil dalam pengarahan visi, motivasi dan panggilan keluarga yang takut akan Tuhan. Sehingga keluarga-keluarga kristen tetap terarah dalam melakukan tugas tanggung jawabnya sebagai orang tua.

Dengan adanya pendampingan gereja terhadap keluarga kristen, maka penulis menyimpulkan bahwa generasi gereja dapat ditolong dan dicegah dari pelecehan seksual yang terjadi di zaman ini.

\section{Gereja membina anak remaja}

Pembinaan anak remaja adalah tanggung jawab gereja. Dalam pembinaan terhadap anak remaja kristen gereja harus memperhatikan kebutuhan anak di dalam perkembangannya. Dalam hal ini gereja harus kreatif dalam melakukan pembinaan melalui program pelayanan gereja. Adapun program pelayanan tersebut yakni dengan mengadakan persekutuan remaja, seminar, KKR (kebaktian kebangunan rohani), penelaahan Alkitab/PA, kebaktian padang dan perkunjungan. Anak Remaja Kristen harus aktif dalam mengikuti persekutuan, terlebih lagi persekutuan anak remaja yang dikhususkan bagi anak remaja. Melalui persekutuan anak remaja mereka dapat mengalami pertumbuhan iman, dan melalui persekutuan yang dibentuk tersebut maka mereka makin muda dikenal, diperhatikan, diperhitungkan dan didukung. Dengan demikian persekutuan anak remaja adalah penting bagi perkembangan iman anak-anak remaja kristen.

\section{Gereja memberikan seminar}

Seminar merupakan suatu metode yang perlu dilakukan oleh gereja dalam membina anak remaja dengan acara yang dirancang untuk kaum remaja secara khusus, yang di dalamnya membahas suatu materi yang sedang berkembang di tengah-tengah anak remaja. Sehingga anak-anak remaja dapat dilindungi dan terkontrol dan lepas dari kegiatan ataupun penyimpangan-penyimpangan yang sering terjadi di kalangan anak remaja.

\section{Gereja membuat kebaktian kebangunan rohani}

Dalam pertumbuhan iman anak remaja KKR (Kebaktian kebangunan rohani) juga merupakan kebutuhan agar mereka semakin dibangun dan kuat, karena KKR merupakan kebaktian kebangunan rohani bagi kaum muda, yang memberikan penyegaran dan pemulihan secara rohani. Di dalam KKR ada pujian, penyembahan dan pemberitaan Firman Tuhan, juga ditambah pertobatan dan kelahiran baru. Sehingga iman anak-anak remaja dapat dibangun dan membangkitkan kerohanian mereka yang mati.

\section{Gereja membuat penelaahan alkitab/PA}

Pembinaan anak remaja dengan kegiatan PA/penelaahan Alkitab, dengan membagi kelompok dari setiap anggota persekutuan remaja, yang dibentuk dengan suasana fleksibel, dilakukan dialog antar anak remaja serta dengan pembina dalam lingkup pembahasan Firman Tuhan. Melalui pembinaan PA/ penelaahan Alkitab ini anak-anak remaja dapat semakin mengenal dan memahami Firman Tuhan. 


\section{Gereja membuat kebaktian padang}

Kebaktian padang merupakan suatu kegiatan ibadah yang diadakan di tempat terbuka, seperti di taman, di halaman, atau di tempat-tempat rekreasi agar mendapat suasana baru. Sehingga anak remaja tidak mudah bosan dengan ibadah ataupun kegiatan persekutuan remaja yang selalu di adakan di gereja.

\section{Gereja membuat perkunjungan}

Dalam pembinaan anak remaja, perkunjungan juga perlu dilakukan. Melalui perkunjungan pengenalan akan pribadi anak remaja jauh lebih muda. Perkunjungan itu sangat penting, sebagaimana yang ditulis oleh Roberth Cowles dalam bukunya mengatakan bahwa:

"Pertama, Dengan berkunjung ke rumah, seorang hamba Tuhan dapat melihat anggota-anggota jemaat dalam keadaan yang sebenarnya. Kedua, Relasi yang harmonis dengan anggota jemaat, para simpatisan, dapat terpelihara dengan baik, sehingga seorang hamba Tuhan senantiasa mendapat keterangan mengenai apa yang terjadi dalam jemaat. Ketiga, Kunjungan ke rumah menyatakan kepada orang-orang bahwa sebagai hamba Tuhan memiliki kasih atau mengasihi mereka. Keempat, Kunjungan kerumah juga memungkinkan waktu ideal bagi seorang hamba Tuhan untuk membina setiap anggota keluarga secara pribadi."

Pembinaan anak remaja sangat dibutuhkan kreatifitas dalam merencanakan program-program pelayanan, dengan tujuan penyampaian Firman Tuhan dan membina anak remaja secara spiritual dan moral. Program-program pembinaan itu dikerjakan dalam berbagai bentuk ibadah dan persekutuan, dan perlu dilakukan dengan rutin dan berkesinambungan. Melalui kegiatan pelayanan yang diprogramkan oleh gereja, penulis yakin anak remaja akan mengalami pertumbuhan iman, dan mereka memiliki persekutuan yang erat dengan Tuhan dan sesama.

\section{Mengadakan sekolah}

Sekolah adalah suatu lembaga atau organisasi yang melakukan kegiatan belajarmengajar berdasarkan kurikulum tertentu yang melibatkan sejumlah orang (murid dan guru). Sekolah merupakan partner kerja dalam mengupayakan pembinaan generasi penerus. Sekolah meneruskan pembinaan yang telah diletakkan dasar-dasarnya dalam lingkungan keluarga. Sekolah menerima tanggung jawab pendidikan berdasarkan kepercayaan keluarga.

Dalam dunia pendidikan sekolah bertugas untuk memperlengkapi anak didik dalam rangka menjadi manusia yang dewasa dan berhasil yakni sebagai berikut:

- Mengembangkan potensi, talenta, atau karunia anak, dan memperlengkapi anak didiknya dengan keterampilan-keterampilan vocational (kerja).

- Memberikan wawasan bagi peserta didik, berkaitan dengan kemampuannya untuk secara efektif memanfaatkan waktu senggangnya (leisure) demi kemuliaan Kristus, dan menyajikan pengajaran humaniora, serta kegiatan-kegiatan ekstra-kurikuler yang mampu menumbuhkan kreativitas.

- Memberikan pemahaman akan panggilan hidup sebagai warga negara yang bertanggungjawab, dan memberikan wawasan yang berguna dalam mendorong anak didik dalam menghadapi tantangan zaman, yang cenderung diwarnai oleh 
penyimpangan-penyimpangan (alinasi) dan keabnormalan. Sekolah harus mengajak peserta didik, dan seluruh pelaku pendidikan untuk memahami perubahan zaman, bersikap kritis terhadap trend yang berkembang di tengah-tengah masyarakat plural.

- Memberikan dorongan guna memungkinkan anak didik menjadi warga gereja yang tangguh, serta memiliki pengetahuan, identitas dan peranan gereja itu sendiri. (kerjasama yang baik antar sekolah dan gereja perlu dibangkitkan).

\section{Kesimpulan}

Jadi melalui uraian di atas, dapat disimpulkan bahwa pendidikan moral dan spiritual kristen sangat penting diterapkan dalam keluarga, terlebih dalam perkembangan anak remaja usia 12-17 tahun.

Dengan adanya penerapan pendidikan moral dan spiritual kristen akan menolong orang tua dalam membimbing anak remajanya menjadi pribadi yang takut akan Tuhan. Anak-anak remaja yang mendapatkan pendidikan moral dan spiritual kristen akan terlihat dalam bersikap, ia akan bertindak sebagaimana orang yang bermoral, anak-anak remaja akan menampilkan perilaku yang baik, dan dapat memenuhi harapan sebagai generasi penerus yang dibanggakan. Dengan kesadaran yang tinggi akan pentingnya pendidikan moral dan spiritual kristen maka segala macam penyimpangan, termasuk kasus pelecehan seksual terhadap anak remaja usia 12-17 tahun dapat dicegah sedini mungkin. 


\section{Kepustakaan}

\section{Buku}

A.Pattinama Yenny, 2013 Pedoman Pelayanan Remaja (Diktat), Tanjung Enim: STTE,

B. Allender Dan Hati, 2001

Yang Luka Kemenagan Atas Derita pelecehan Seksual, (Jakarta:BPK Gunung Mulia

Banawiratma JB, 2012

Pelayan Spiritualitas Dan Pelayanan, Yogyakarta: Taman Pustaka Kristen IKPI

Elisabeth Eiodia 2016 Coverstory: Tuhan Mengasishiku.", Majalah BAHANA

D. Gunarsa Singgih, 1982

Dobson James, 2005 Masalah Membesarkan Anak, Bandung: Yayasan Kalam Hidup

Draver James, 1988 Kamus Psikologi, Jakarta: Bina Aksara,

Dyck Anni, 1982 Tantangan Dan Kebutuhan Remaja, Batu Malang: Departemen Pembinaan Anak Dan Pemuda/YPPII,

Fields Doug,

tt Apakah Kaum Muda Dan Remaja Gereja Memiliki Tujuan, Malang: Gandum Mas.

Go Setiawani Mary, 2004 Menerobos Dunia Anak, Bandung: Yayasan Kalam Hidup

Herlianto, 1995 Aids dan Perilaku Seksual, Bandung: Yayasan Kalam Hidup

Kasan Tholib, 2009 Dasar-Dasar Pendidikan, Jakarta Timur

L. Thompson Marjorie, 2012 Keluarga Sebagai Pusat Pembentukan, Jakarta: BPK. Gunung Mulia La Haye Beverly, 2002 Memahami Temperamen Anak, Bandung: Yayasan Kalam Hidup,

La Haye Beverly, 2002

Lawrence Bill, 1997 Menggembalakan Dengan Hati, Yogyakarta: PBMR Andi

M. Narramore Clyde, 1961 Menolong Anak Anda Bertumbuh Dalam Iman, Bandung, Kalam Hidup

Mulia Hutabarat Tonny,

Memahami Temperamen Anak Anda, Bandung: Yayasan Kalam Hidup

2015

Kekerasan Seksual tidak Dibenarkan, Majalah BAHANA 
Norman Wraight $\mathrm{H}$, 2006 Konseling Krisis-Membantu Orang Dalam Krisis Dan Stres, MalangJawa Timur: Gandum Mas

Porter R.J, 2005 Katekisasi Masa Kini, Jakarta: Yayasan Komunikasi Bina Kasih

R. Dunn Richard, 2001 Membentuk Kerohanian Anak Muda, Malang: Literatur Perkantas

Sanders Bil, 1995

Dari Remaja Untuk Orang Tua, Bandung: Yayasan Kalam Hidu Sidjabad BS, 2011 Membangun Pribadi Unggul, Yogyakarta: ANDI,

Sorotan, 2016 Berita Siang TV One (Senin, 12 Sepetember, pukul 12: $30 \mathrm{Wib}$ ) Suyanto \& Sri Sanituti Hariadi, 2002 Bagong Krisis \& Child Abuse, Surabaya: Airlangga University Press Stanley Heath W, 2010 Teologi Pendidikan, Bandung: Yayasan Kalam Hidup

\section{Internet}

- File:///F:/Fakta faktaMengejutkanKasusYuyunyangBikinKitaTakTegaMendengarnyalDNtimes.com.h tm, Online, 15 Agustus 2016

- Http://korananakindonesia.wordpress.com/2009/12/05perlunya-etiket-dalampergaulan-remaja-masa-kini/, Online, 15 Agustus 20016

- www.aidsindonesia.or.id, Online, 17 Agustus 20016 